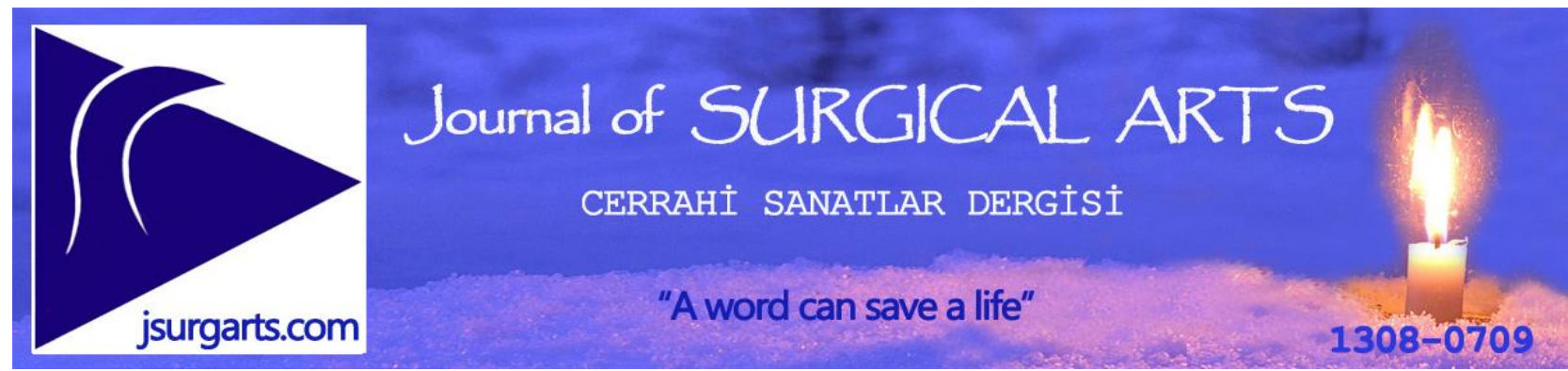

Clinical Practice Study

\title{
Effects of propofol, desflurane and isoflurane on perioperative blood glucose level in intracranial mass operation: A randomized controlled trial
}

\section{İntrakranial kitle operasyonu geçirecek hastalarda propofol, desfluran ve isofluranın perioperatif kan glukoz düzeyine etkileri}

\section{Yonca Özvardar Pekcan', Atilla Şencan², Kaan Katırcıoğlu², Murat Aksun², Hüseyin Serdar Savacı²} Turkey.

Department of Anesthesiology and Reanimation ${ }^{1}$, Başkent University School of Medicine, Ankara,

Department of Anesthesiology and Reanimation ${ }^{2}$, Katip Çelebi University Atatürk Education and Research Hospital, İzmir, Turkey.

Address: Dr. Yonca Özvardar Pekcan (https://orcid.org/0000-0002-0991-7435), yncapek@gmail.com

How to cite: Pekcan YV, Şencan A, Katırcıoğlu K, Aksun M, Savacı HN. Effects of propofol, desflurane and isoflurane on perioperative blood glucose level in intracranial mass operation: A randomized controlled trial. J Surg Arts: 2021;14(1): 41-47. DOI: https://doi.org/10.14717/jsurgarts-210107

Received: 05.02.2021 Accepted: 17.02.2021

\section{ABSTRACT}

The aim of this study is to compare the effects of the propofol, desflurane and isoflurane on blood glucose levels in cranial surgery.

Ninety, ASA I-II patients aged between 18-60 years old were scheduled for study. Induction was performed with fentanyl, propofol and cisatracurium in all patients. Anaesthesia was maintained using propofol 4-6 $\mathrm{mg} / \mathrm{kg} / \mathrm{h}$ in propofol group (Group P), desflurane and isoflurane 0.5-1 MAC in group desflurane (Group D) and group isoflurane (Group I). Remifentanil infusion was applied $0.5 \mu \mathrm{g} / \mathrm{kg} / \mathrm{min}$ in all groups. Plasma glucose (PG) levels, systolic arterial pressure (SAP), diastolic arterial pressure, mean arterial pressure and heart rate measured.

In the 1st, 2nd and 5th hour, PG levels were significantly lower in group P than group D. In the 2nd and 3rd hour, PG levels were significantly lower in group P than group I ( $p<0.05)$. In addition, SAP values in group $\mathrm{D}$ were found to be significantly lower than group $\mathrm{P}$ and group $\mathrm{I}$.

With this study, it was concluded that total intravenous anesthesia with propofol infusion in intracranial mass surgery is more effective than inhalation anesthesia such as desflurane and isoflurane in preventing the hyperglycemic response caused by surgical stress.

Keywords: Blood glucose level; brain neoplasms; intravenous anethesia.

\section{ÖZET}

$\mathrm{Bu}$ çalışmanın amacı intrakranial tümör cerrahisinde propofol, isofluran ve desfluranın kan şekeri düzeylerine etkilerini karşılaştırmaktır.

$\mathrm{Bu}$ çalışmaya yaşları 18-60 arasında 90 hasta dahil edildi. İndüksiyon tüm hastalarda fentanil, propofol ve cis-atracurium, ile uyguland. Anestezi idamesi isofluran grubunda (Grup İ) 0.5-1 MAC konsantrasyonda isofluran, desfluran grubunda (Grup D) 6-8 MAC konsantrasyonda desfluran ve propofol grubunda (Grup P) 4-6 $\mathrm{mg} / \mathrm{kg}$ propofol ile sağlandı. Tüm hastalara $0.5 \mu \mathrm{gr} / \mathrm{kg} / \mathrm{dk}$ remifentanil infuzyonu uygulandı. Tüm hastaların kan şekeri düzeyleri, sistolik (SAB), diyastolik (DAB) ve ortalama (OAB) arter basınçları ve kalp atım hızları kaydedildi.

Kan şekeri düzeyleri karşılaştırıldığında grup P'nin değerleri grup D'ye göre operasyonun 1, 2, 3. ve 5. saatinde anlamlı derecede düşük bulundu. Operasyonun 2. ve 3.saatinde grup P'de grup I'ye göre anlamlı derece- 
de düşük bulundu ( $\mathrm{p}<0.05)$. Ayrıca grup D’de SAB değerleri grup P ve grup I'ye göre anlamlı derecede düşük bulundu.

Bu çalışma ile intrakraniyal kitle ameliyatlarında propofol infüzyonu ile yapılan total intravenöz anestezinin, cerrahi stresin neden olduğu hiperglisemik yanıtı önlemede desfluran ve izofluran gibi inhalasyon anestezisine göre daha etkili olduğu sonucuna varıldı.

Anahtar kelimler: Kan şekeri; beyin tümörleri; intravenöz anestezi.

\section{INTRODUCTION}

Surgery or trauma often leads to neural, endocrinal, metabolic, and humoral responses depending on their magnitudes. As a result of these responses, while some changes in protein homeostasis, hypermetabolism, carbohydrate metabolism can be observed, an increase in lipolysis with sodium and, water retention is observed. As insulin level drops immediately during and after surgery, it then recovers to their normal levels. With the onset of general anesthesia, blood glucose levels increase and reach their peak levels within 30 minutes, decreasinge to normal values within 60 minutes in a normal individual (1). The cause of hyperglycemia is partly associated with the direct effect of anesthetics and partly with the increase in the secretion of pituitary and adrenocortical hormones as a result of sympathetic stimulation. Fear, stormy induction, hypoxia (insufficient ventilation, respiratory obstruction, anemia, cardiopulmonary disorders), and the sympathetic stimulating effect of the agent which is used play a role in adrenaline release (2).

Particularly, inhalation agents depress the glucose-insulin response (1). Some studies have established an increase in plasma glucose concentration without surgical stress during isoflurane anesthesia (3). Propofol has been revealed to reduce glucose metabolism by $15-55 \%$, also to keep blood glucose level unchanged during surgery and also to maintain the balance between cerebral blood flow and cerebral oxygen consumption at infusion doses which cause burst suppression in the electroencephalogram (EEG) (4). Such effects of hyperglycemia as immunosuppression, electrolyte imbalance, and increased carbon dioxide $(\mathrm{CO} 2)$ production are prominent ones in terms of affecting postoperative mortality and morbidity. Especially, in intracranial tumor surgery, normoglycemia should be provided due to such reasons as the magnitude of the surgery, the importance of assessing the state of consciousness, and the already increased intracranial pressure elevating with the effect of hyperglycemia. Therefore, the selection of agents that would not cause hyperglycemia has become more and more important. In this study, the effects of propofol, desflurane, and isoflurane on perioperative blood glucose levels were evaluated in patients scheculed to undergo an intracranial mass operation.

\section{MATERIAL and METHOD}

This study was carried out on neurosurgical patients scheduled to have a craniotomy operation, after obtaining the approval of the local Ethics Committee of Izmir Atatürk Training and Research Hospi- tal (EK-1) and informed consent of patients. The study included 90 patients aged between 18-60 years who were assessed as ASA (American Society of Anesthesiology) I-II and who agreed to participate in the study. Patients with cardiovascular, renal, hepatic, or endocrine system diseases and patients on drugs affecting carbohydrate metabolism were excluded from the study. Patients taken to the operating room without undergoing premedication were monitored with the Datex Ohmeda (S/5 Aestiva 3000- the USA) monitor device. Demographic data including age, gender, body mass index (BMI), ASA score, and operation times were recorded. Following standard monitoring including electrocardiography (ECG), invasive blood pressure (IBP), body temperature, and peripheral oxygen saturation $(\mathrm{SpO} 2)$, standard anesthesia protocol was then applied and, induction and intubation were provided with $2 \mu \mathrm{gr} / \mathrm{kg}$ fentanyl, $2 \mathrm{mg} / \mathrm{kg}$ propofol, 0.15 $\mathrm{mg} / \mathrm{kg}$ cis-atracurium for all patients. The patients were then randomly separated into three groups comprising of 30 people. Maintenance of anesthesia with isoflurane was achieved in Isoflurane Group (Group I) with a dose adjusted at a concentration of 0.5-1 MAC, while in Desflurane Group (Group D) the same was achieved with desflurane at 6-8 MAC concentration and in Propofol Group (Group P) with propofol 4-6 $\mathrm{mg} / \mathrm{kg} / \mathrm{h}$. Also, $0.5 \mu \mathrm{gr} / \mathrm{kg} / \mathrm{min}$ remifentanil infusion was applied to all groups as maintenance. During the operation, a $0.9 \% \mathrm{NaCl}$ solution was applied to the patients. All patients underwent blood glucose level measurement with a blood glucose meter (Optium Abbot brand) preoperatively(TO), at the 2nd minute (T1) post-intubation, at the 5th minute (T2) following the application of anesthetic agent, at the 5th minute following the onset of the surgical incision (T3), and then respectively at the 1st (T4), 2nd (T5), 3rd (T6), 4th (T7) and lastly at the 5th hour of the operation (T8), which was recorded with systolic arterial pressure values measured at the same time.

\section{Statistical analysis}

Before starting the study, it was calculated that there should be 30 patients in each group for the changes in blood glucose levels (based on the increase in blood glucose from $110 \mathrm{mg}$ dl-1 to $120 \mathrm{mg} \mathrm{dl}-1$ ) to give a power analysis result with a significance level of $80 \%$ so that $\alpha=0.05, \beta=0.20$.

While conducting statistical analysis, OneWay ANOVA, Post Hoc (Tukey's), Kruskal Wallis H test, Mann Whitney U Test; Chi-Square Test and Fisher's Exact Test were used to compare our categorical variables, and on the other hand, Paired Samples 
t-Test was used to evaluate the groups between themselves. Numerical variables were summarized as Mean \pm SD and categorical variables as sum and percentage. All analyzes were done in SPSS 10.0 for the Windows statistics program with $95 \%$ confidence. $\mathrm{p}<0.05$ was considered statistically significant.

\section{RESULTS}

Ninety patients, who were evaluated in 3 groups each of which consisted of 30 people, participated in the study. When the mean age was compared between the groups, it was determined that the mean age of the Group D was higher than that of Group P (p $<0.05)$. No statistically significant difference was found between the groups in terms of gender, BMI, operation times and ASA distribution (Table 1).

When the groups were compared in terms of blood glucose levels over time, the values of Group P were significantly lower compared to group D at the 1st hour of operation (T4) $(99.13 \pm 16.14-117.07 \pm$ $21.82 \mathrm{p}=0.02$ ), at the 2nd hour of the operation (T5) $(109.07 \pm 21.39-125.22 \pm 21.33 \mathrm{P}=0.034)$, at the $3 \mathrm{rd}$ hour (T6) $(111.86 \pm 19.14-137.39 \pm 28.16 \mathrm{p}=0.004)$ and at the 5th hour of operation (T8) (100.83 $\pm 13.24-$ $138.50 \pm 32.45 \mathrm{p}=0.044)$.

In terms of blood glucose level evaluations, the levels in the Group P were again found to be significantly lower compared to Group I at the 2nd (T5) $(109,07 \pm 21,39-123,44 \pm 32,35 \mathrm{p}=0,034)$ and at the 3 rd hour of the operation (T6) $(111,86 \pm 19,14$ $133,95 \pm 29,22 \mathrm{p}=0,004)$ (Table 2) (Figure 1). When the SAP values of the groups were compared by periods, the values of group D compared to group $\mathrm{P}$ were significantly lower at the 5 th minute (T2) $(102.57 \pm$ $15.93-112.47 \pm 14.46 \mathrm{p}=0.037)$ at the 5 th minute after the onset of the operation (T3) $(106.86 \pm 15.33$ $117.97 \pm 8.48 \mathrm{p}=0.08)$, at the 1 st hour of the operation (T4) $(99.68 \pm 11.15-107.23 \pm 13,22 \mathrm{p}=0.045)$, at the 2nd hour of operation (T5) $(100.70 \pm 8.38$ $112.33 \pm 12.06 \mathrm{p}=0.01)$, at the 4 th hour of operation (T7) $(101.56 \pm 10,47-116.67 \pm 14.07 \mathrm{p}=0.014)$. Again, when SAP values were compared at the 4 th hour of the operation, the values of group D were found to be significantly lower than group I (101.56 \pm 10.47-126.11 $\pm 21.91 \mathrm{p}=0.014)$ (Table 3).

Table 1: Demographic data of the patients.

\begin{tabular}{|l|c|c|c|c|c|}
\hline & Ísoflurane & Desflurane & Propofol & Anova & Post Hoc \\
\hline Age at operation & $44,40 \pm 11,69$ & $47,53 \pm 12,56$ & $39,30 \pm 14,09$ & 0,048 & + \\
\hline BMI $\left(\mathrm{kg} / \mathrm{m}^{2}\right)$ & $25,63 \pm 3,37$ & $24,94 \pm 3,59$ & $25,36 \pm 4,71$ & 0,791 & \\
\hline Operation time $(\mathrm{min})$ & $267,17 \pm 83,60$ & $279,33 \pm 77,94$ & $284,83 \pm 72,07$ & 0,670 & \\
\hline Gender n (\%) & & & & $\mathrm{X}^{2}$ & \\
\hline Male & $14(46,7)$ & $17(56,7)$ & $16(53,3)$ & 0,732 & \\
\hline Female & $16(53,3)$ & $13(43,3)$ & $14(46,7)$ & & \\
\hline +Group D-Group P & & & &
\end{tabular}

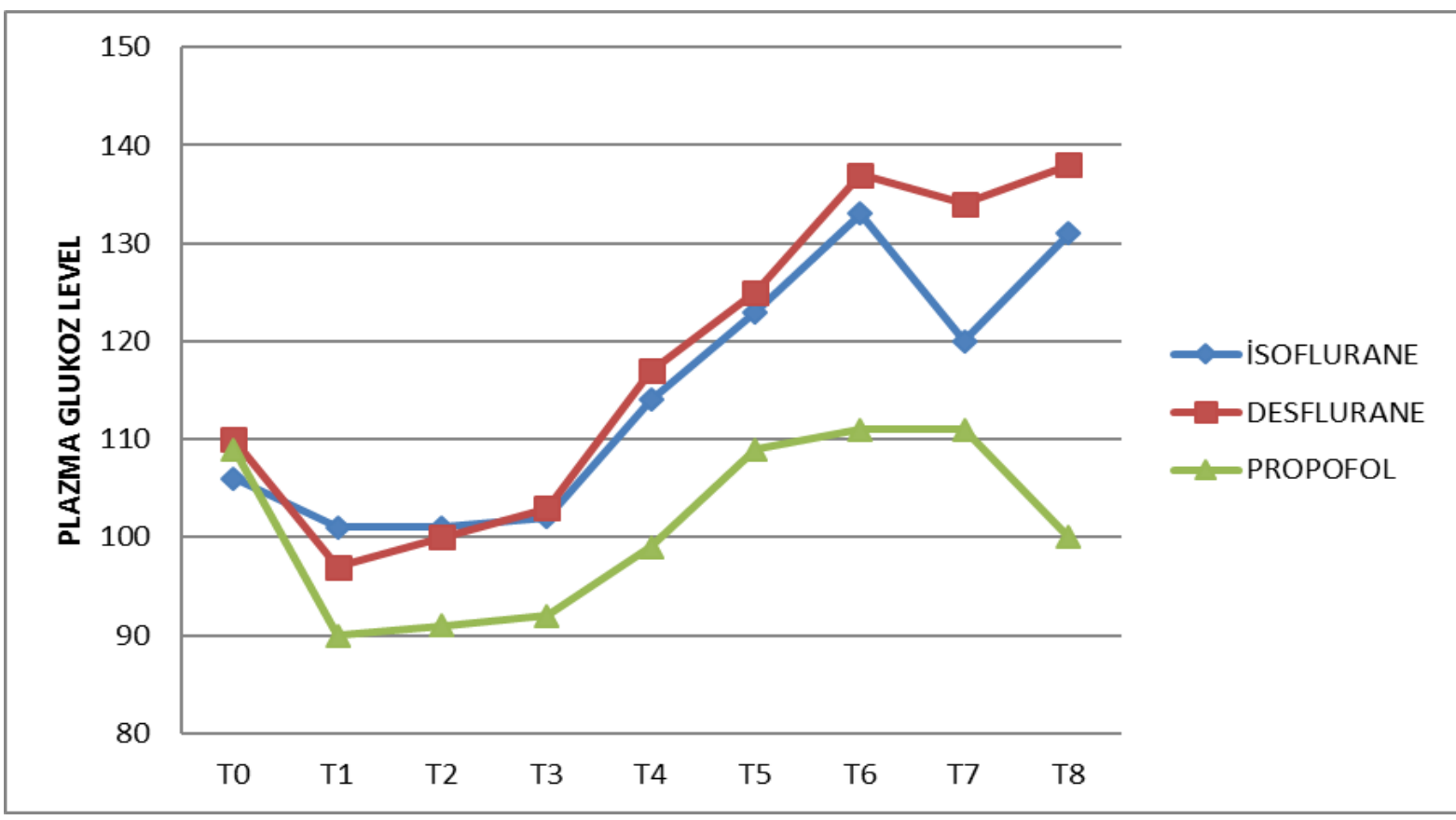

Figure 1: Plasma glucose levels according to time between groups. 


\begin{tabular}{|c|c|c|c|c|c|}
\hline \multicolumn{7}{|c|}{ Table 2: Plasma glucose levels according to time between groups. } \\
\hline $\begin{array}{c}\text { Plasma glucose } \\
\text { level }\end{array}$ & İsoflurane & Desflurane & Propofol & Anova & Post Hoc \\
\hline T0 & $106,37 \pm 21,09$ & $110,77 \pm 22,48$ & $109,93 \pm 19,84$ & 0,695 & \\
\hline T1 & $101,63 \pm 26,21$ & $97,80 \pm 20,66$ & $90,43 \pm 17,26$ & 0,133 & \\
\hline T2 & $101,23 \pm 23,02$ & $100,10 \pm 21,74$ & $91,60 \pm 14,63$ & 0,135 & \\
\hline T3 & $102,93 \pm 21,62$ & $103,38 \pm 21,12$ & $92,57 \pm 15,56$ & 0,060 & \\
\hline T4 & $114,13 \pm 21,47$ & $117,07 \pm 21,82$ & $99,13 \pm 16,14$ & 0,002 & + \\
\hline T5 & $123,44 \pm 32,35$ & $125,22 \pm 21,33$ & $109,07 \pm 21,39$ & 0,034 & $\#,+$ \\
\hline T6 & $133,95 \pm 29,22$ & $137,39 \pm 28,16$ & $111,86 \pm 19,14$ & 0,004 & $\#,+$ \\
\hline T7 & $120,78 \pm 19,06$ & $134,78 \pm 23,33$ & $111,11 \pm 22,08$ & 0,059 & \\
\hline T8 & $131,67 \pm 22,68$ & $138,50 \pm 32,45$ & $100,83 \pm 13,24$ & 0,044 & + \\
\hline \#Group İ-Group P, +Group D-Group P & & & \\
\hline
\end{tabular}

Table 3: SAP values according to time between groups.

\begin{tabular}{|c|c|c|c|c|c|}
\hline SAP & İsoflurane & Desflurane & Propofol & Anova & Post Hoc \\
\hline T0 & $134,67 \pm 19,24$ & $143,83 \pm 22,47$ & $138,67 \pm 20,74$ & 0,239 & \\
\hline T1 & $124,97 \pm 19,02$ & $123,63 \pm 22,69$ & $129,93 \pm 23,59$ & 0,503 & \\
\hline T2 & $110,57 \pm 16,22$ & $102,57 \pm 15,93$ & $112,47 \pm 14,46$ & 0,037 & + \\
\hline T3 & $112,0 \pm 15,37$ & $106,86 \pm 15,33$ & $117,97 \pm 8,48$ & 0,008 & + \\
\hline T4 & $102,80 \pm 9,64$ & $99,68 \pm 11,15$ & $107,23 \pm 13,22$ & 0,045 & + \\
\hline T5 & $105,71 \pm 13,37$ & $100,70 \pm 8,38$ & $112,33 \pm 12,06$ & 0,001 & + \\
\hline T6 & $109,63 \pm 17,96$ & $102,28 \pm 8,53$ & $111,55 \pm 13,05$ & 0,099 & \\
\hline T7 & $126,11 \pm 21,91$ & $101,56 \pm 10,47$ & $116,67 \pm 14,07$ & 0,014 & $*,+$ \\
\hline T8 & $121,33 \pm 7,57$ & $107,83 \pm 8,57$ & $111 \pm 11,74$ & 0,124 & \\
\hline SAP: Systolic Arterial Pressure, *Group İ-Group D, +Group D-Group P & & \\
\hline
\end{tabular}

\section{DISCUSSION}

The results of this study showed us that, inhalation agents cannot prevent hyperglycemia, while propofol suppresses the response and even decreases it at the 5th hour of the operation according to preoperative blood glucose levels in patients operated due to intracranial mass. Anesthesia and the accompanying surgery cause endocrine and metabolic changes by creating stress. As the stimuli arising from the surgical site activates the hypothalamic-pituitary hormonesecretion and the sympathetic system, the release of catabolic hormones such as cortisol and catecholamine tend to increase, while the release of such anabolic hormones as insulin and testosterone decreases. Insulin level tends to decreases immediately during and after surgery and then recovers to normal levels, which can also rise above normal levels following major surgical procedures; However, insulin may be metabolically ineffective during this period. This possibility and surgery-induced hyperglycemic response can have significant consequences (1).

Electrolyte imbalance, immunosuppression, osmatic diuresis and increased $\mathrm{CO} 2$ production caused by hyperglycemia create serious problems in the perioperative period. The increase in venous pressure in cerebral vessels and the increase in plasma osmolality elevate intracranial pressure with the effect of hypercapnia. This situation reaches dangerous levels for patients with an increased intracranial pressure due to intracranial mass. Also, the risk of herniation increases. Also, blood supply to the brain is negatively affected. Patients' Glasgow coma scales get worse (5). It also increases the bleeding in the surgical field by affecting the coagulation system. Electrolyte imbalance, acidosis, and hyponatremia caused by insulin deficiency also adversely affect the subsequent condition of the patient (6). Moreover, hyperglycemia increases susceptibility to infections and to prolonged wound healing with phagocytosis dysfunction. For these reasons, many studies have been carried out to suppress the perioperative increase in blood glucose level.

In studies conducted on humans individuals without previous history of surgery, it was shown that cortisol, epinephrine, norepinephrine concentrations increased with isoflurane anesthesia, thus glucose intolerance was observed up to 1.5 MAC independent of the dose, and hyperglycemic response developed with an increase in endogenous glucose production causes by the decrease in glucose use in patients undergoing surgery $(7,8)$. It is also stated that if the duration of anesthesia with isoflurane is prolonged, glucagon concentration decreases, which may increase blood glucose (9). In another study, they also reported that isoflurane anesthesia caused impairment of insulin secretion by reducing glucose-dependent adenosine triphosphate-sensitive potassium channel activity in 
pancreatic $\beta$ cells (10). In animals, isoflurane has also been shown to increase blood glucose by weakening glibenclamide-induced insulin secretion during the late phase of IVGTT $(7,9)$. This study also supports these results. That was found the blood glucose level increased starting at the 5th minutes of the surgical incision (T3) in patients who were administered isoflurane, which peaked at the 3rd hour (T6), and slightly decreased at the 4th hour (T7), however, it increased again after the 5th hour (T8). Based on these findings, it was thought that the increase at the 5th minute of the incision might be due to surgical stress.

In a study conducted with desflurane in the literature, it was reported that desflurane should be used carefully and only at low concentrations in patients with a risk of increased intracranial pressure due to cerebral vasodilation (11). Based on these findings, any complications other than low systolic arterial pressure (SAP) values were encountered with desflurane at 6-8 MAC concentrations. In a study comparing desflurane-remifentanil and desflurane-clonidine anesthesia in the literature, they reported that the perioperative blood glucose level was lower in the desflurane-remifentanil group (12). Therefore, remifentanil was used in all patients in this study. In another study, they found that the perioperative blood glucose level increased with the use of desflurane and returned to normal within 24 hours postoperatively (13). On the other hand, Gülbayrak et al. (14) found in their study with desflurane that the blood glucose level increased at the 30th-minute perioperatively, decreased after 24 hours but remained higher than the preoperative values. In a study conducted with neurosurgical patients, it was showed that desflurane and isoflurane have the same effects on blood glucose levels (15). In this study, blood glucose levels in the desflurane group increased significantly starting from the 5th minute (T3) of the incision and were significantly higher at the 1st (T4), 2nd (T5), 3rd (T6), and 5th (T8) hours of the operation compared to the propofol group. This similarty shows particularly that inhalation agents depress the insulin response stimulated against blood glucose. In the literature, it has been reported that intravenous anesthetics suppress metabolic and endocrine responses to anesthesia and surgical stress better $(4,16)$. This study also supports these findings. In the group in which we administered propofol, blood glucose levels only slightly exceeded the preoperative values at the 3rd hour (T6) of the operation and decreased again at the 4th hour (T7). Even at the end of the 5 th hour, it was lower than the preoperative values. In studies conducted on animals, it has been reported that the mitochondrial damage in the heart caused by hyperglycemia and hexokinase was partially prevented in patients who were administered propofol, and the damage could be significantly prevented in those who were administered opioid with propofol $(17,18)$. In a study conducted in patients who underwent craniotomy, it was shown that the increase in blood glucose level was decreased in patients who were administered remifentanil and propofol infusion compared to those who were administered remifentanil and isoflurane (19).

It has been shown in various studies that hyperglycemia causes endothelial dysfunction (20). Excess production of superoxide induced by hyperglycemia is one of the important causes of vascular dysfunction in acute hyperglycemia and diabetes mellitus (21-23). Propofol has been reported to have potential antioxidant properties similar to phenol-based free radical scavengers such as vitamin $E$, due to its chemical structure (24). In animals, propofol is protective against cerebral microvascular damage caused by increased oxidative stress (25). Also, in another animal study, it was reported that propofol caused systemic insulin resistance and caused a decrease in insulin-stimulated glucose uptake in skeletal and cardiac muscle (26). However, a later study did not support this (27). Ishi et al. (28) also reported that high-dose $(15-30 \mathrm{mg} / \mathrm{kg} / \mathrm{h})$ propofol administration reduces lactate accumulation and edema in the ischemic area in hyperglycemic rats, and they recommended the use of propofol to prevent neuronal damage during neurosurgery operations, especially in diabetic patients.

In another study, they compared propofol and sufentanil with enflurane anesthesia and stated that the increase in plasma cortisol and catecholamine concentrations were prevented in the propofol-sufentanil group, and the hyperglycemic response was reduced, but this decrease was present only during surgery (29). The researchers attributed the increase after surgery to the short half-time of propofol-sufentanil and also to an increase in the glucagon/insulin ratio. Kim et al. (30) reported that the patients with type 2 diabetes who underwent pulmonary surgery were present with perioperative hyperglycemia, though they did not detect a difference in the incidence of sevoflurane and propofol anesthesia during the operation, and that it was, however, significantly lower in the propofol group at 2 nd postoperative hours. The researchers attributed this to opioid used at higher doses during propofol anesthesia.

\section{Study Limitations}

The limitations of this study are that the levels of insulin, cortisol, and catecholamines were not measured. Also, blood glucose level, pain, cortisol, catecholamine, and insulin could not be monitored in the postoperative period. Therefore, this study does not reveal how long this positive effect of propofol lasts. We believe that further studies, comprising the postoperative period, need to be conducted to evaluate insulin, cortisol, and catecholamine levels as well as blood glucose levels in the future.

\section{Conclusion}

In conclusion, that was found inhalation agents fail to prevent hyperglycemia in this study. However, it was observed that propofol suppressed this response and even reduced it to lower levels at the 
5th hour of the operation compared to preoperative blood glucose levels. Considering these results, it was concluded that propofol and remifentanil infusion can be a good option in some particular cases such as neurosurgery in which blood glucose levels are not desired to increase, or in cases in which the operation time with an already high blood glucose level is expected to exceed 4 hours.

\section{REFERENCES}

1. Kayhan Z: Endokrin/Metabolik Sistem ve Anestezi. In: Kayhan Z (Ed), Klinik Anestezi. Istanbul, FL: Logos Press, 2019, p:426-28.

2. Schricker T, Latterman R, Schreiber M, Geisser W, Georgieff M, Radermacher P. The hyperglisemic responce to surgery; pathophysiology, clinicial implications and modification by the anaesthetic tecnique. Clin intensive care. 1998;9:118-28.

3. Horber FF, Krayer S, Miles J, Cryer P, Rehder K, Haymond MW. Isoflurane and whole body leucine, glucose and fatty acid metabolism in dogs. Anaesthesiology 1990;73:82-92.

4. Behdad S, Mortazavizadeh A, Ayatollahi V, Kha$\operatorname{div} \mathrm{Z}$, Khalilzadeh S. The effects of propofol and isoflurane on blood glucose during abdominal hysterectomy in diabetic patients. Diabetes Metab J 2014;38:311-6.

5. Rovlias A, Kotsou S. The influence of hyperglycemia on neurosurgical outcome in patients with severe head ingury. Neurosurgery. 2000;46:342-3.

6. Keçik Y, Ünal N. Nöroanestezi. In: Keçik Y, Ünal N (ed). Ankara, FL: Atlas Press, 2000, p:25-6.

7. Lattermann R, Schricker T, Wachter U, Georgieff $\mathrm{M}$, Goertz A. Understanding the mechanisms by which isoflurane modifies the hyperglycemic response to surgery. Anesth Analg 2001:93:121-7.

8. Tanaka T, Nabatame H, Tanifuji Y. Insulin secretion and glucose utilization are impaired under general anesthesia with sevoflurane as well as isoflurane in a concentration independent manner. J Anesth 2005;19:277-81.

9. Nishiyama T, Yamashita K, Yokoyama T. Stress hormone changes in general anesthesia of long duration: Isoflurane-nitrous oxide vs sevofluranenitrous oxide anesthesia. J Clin Anesth 2005;17: 586-91.

10. Tanaka K, Kawano T, Tomino T, Kawano H, Okada T, Oshita S, et al. Mechanisms of impaired glucose tolerance and insulin secretion during isoflurane anesthesia. An 7 esthesiology 2009;111: 1044-51.

11. Luginbuehl IA, Fanzca MJF, Karsl1 C, Bissonnette B. Cerebral blood flow velocity in children anaesthetized with desflurane. Paediatric Anaesthesia 2003;13:496-500.

12. Baloğlu A, Sabuncu C, Bilir A, Ekemen S. Comparison of the effects of remifentanil and clonidine infusion with desflurane anaesthesia in abdominal surgery 2005;33:11-7.
13. Weiskopf RB, Eger II EI, Ionescu P, Yasuda N, Chalan MK, Freire B, et al. Desflurane does not produce hepatic or renal injury in human volunteers. Anesth Analg. 1992;74:570-4.

14. Gülbayrak H, Erhan ÖL, Önal AS, Yaşar MA, Gülbayrak K. Monitorization of Neuromuscular Block and Anesthesia Depth of Inhalation and Propofol Anesthesia with the Comparison of Hemodynamic and Neuroendocrine Responses. F.Ü. Sağlık Bil. Dergisi 2004;18:131-7.

15. Akavipat P, Polsayom N, Pannak S, Punkla W. Blood Glucose Level in Neurosurgery. Is It Different Between Isoflurane and Desflurane Anesthesia? Acta Med Indones-Indones J Intern Med 2009;41:121-5.

16. Crozıer TA, Muller JE, Quittkat D, Sydow M, Wuttke W, Kettler D. Effect of anaesthesia on the cytokine responses to abdominal surgery. British Journal of Anaesthesia1994;72:280-5.

17.Zuurbier CJ, Keijzers PJM, Koeman A, Van Wezel HB, Hollmann MW. Anesthesia's Effects on Plasma Glucose and Insulin and Cardiac Hexokinase at Similar Hemodynamics and Without Major Surgical Stress in Fed Rats. Anesth Analg 2008;106:135-42.

18. Kitamura T, Ogawa M, Kawamura G, Sato K, Yamada Y. The Effects of Sevoflurane and Propofol on Glucose Metabolism Under Aerobic Conditions in Fed Rats. Anesth Analg 2009; 109: 147985.

19. Cok OY, Ozkose Z, Pasaoglu H, Yardım S. Glucose response during craniotomy: propofolremifentanil versus isoflurane-remifentanil. Minerva Anestesiol 2011;77:1141-8.

20. Beckman JA, Goldfine AB, Gordon MB, Creager MA: Ascorbate restores endothelium dependent vasodilation impaired by acute hyperglycemia in humans. Circulation 2001;103:1618-23.

21. Kinoshita H, Azma T, Iranami H, Nakahata K, Kimoto Y, Dojo M, et al. Synthetic peroxisome proliferator-activated receptor- $\gamma$ agonists restore impaired vasorelaxation via ATP-sensitive $\mathrm{K}+$ channels by high glucose. J Pharmacol Exp Ther 2006;318:312-8.

22. Karashima Y, Oike M, Takahashi S, Ito Y. Propofol prevents endothelial dysfunction induced by glucose overload. Br J Pharmacol 2002;137:68391.

23. Cosentino F, Hishikawa K, Katusic ZS, Luscher TF. High glucose increases nitric oxide synthase expression and superoxide anion generation in human aortic endothelial cells. Circulation 1997; 96:25-8.

24. Murphy PG, Myers DS, Davies MJ, Webster NR, Jones JG. The antioxidant potential of propofol (2,6-diisopropylphenol). Br J Anaesth 1992;68: 613-8.

25. Nakahata K, Kinoshita H, Azma T, Matsuda N, Hama-Tomioka K, Haba M,et al. Propofol Restores Brain Microvascular Function Impaired by 
High Glucose via the Decrease in Oxidative Stress. Anesthesiology 2008;108:269-75.

26. Yasuda Y, Fukushima Y, Kaneki M, Martyn JAJ. Anesthesia with propofol induces insulin resistance systemically in skeletal and cardiac muscles and liver of rats. Biochemical and Biophysical Research Communications 2013;431:81-5.

27. Zhu M, Chen J, Jiang H, Miao C. Propofol protects against high glucose-induced endothelial adhesion molecules expression in human umbilical vein endothelial cells. Cardiovasc Diabetol 2013;12:1-13.

28. Ishii H, Arai T, Segawa H, Morikawa $\mathrm{S}$, Inubushi T, Fukuda K. Effects of propofol on lactate accumulation and oedema formation in focal cerebral ischaemia in hyperglycaemic rats. $\mathrm{Br} \mathbf{J}$ Anaesth 2002;88:412-7.

29. Schriker T, Carli F, Schreiber M, Wachter U, Geisser W, Lattermann R, et al. Propofol/sufentanil Anesthesia Supresses the Metabolic and Endocrine Response During, Not After, Lower Abdominal Surgery. Anesth Analg 2000;90:450-5.

30. Kim H, Han J, Jung SM, Park SJ, Kwon NK. Comparison of sevoflurane and propofol anesthesia on the incidence of hyperglycemia in patients with type 2 diabetes undergoing lung surgery. Yeungnam Univ J Med 2018;35:54-62. 